\title{
The Effect of Boiling Temperature in Beef and Pork Meatball Making Process on DNA Detection using Real Time Polymerase Chain Reaction (RT-PCR) Method
}

\author{
Zilhadia $^{1^{*}}$, Sabar Pambudi ${ }^{2}$, Yusuf Nur Pradana ${ }^{3}$, Arvian Istara ${ }^{4}$ \\ \{zilhadia@uinjkt.ac.id', sabar2508@gmail.com²,yusuf.pradana15@mhs.uinjkt.ac.id ${ }^{3}$, \\ arvianistara@gmail.com $\left.{ }^{4}\right\}$ \\ *corresponding author
}

Pharmacy Study Program, Faculty of Health Sciences UIN Syarif Hidayatullah Jakarta, Ciputat, 15419. Indonesia ${ }^{1,3,4}$

Center for Pharmaceutical and Medical Technology, Agency for the Assessment and Application of Technology, Jakarta, Indonesia ${ }^{2}$

\begin{abstract}
Boiling meat in meatball making process can cause DNA degradation. This study aims at determining the effect of boiling temperature on beef and pork DNA detection in meatball samples using Real Time Polymerase Chain Reaction (RT-PCR). DNA of beef, pork, beef meatballs, pork meatballs and beef-pork meatballs boiled at $8^{\circ} \mathrm{C}, 90^{\circ} \mathrm{C}$, and $100^{\circ} \mathrm{C}$ were isolated using the Wizard Genomic DNA Purification Kit and amplified using the RT-PCR. The result has shown DNA of beef meatball, pork meatball, and beef-pork meatball samples heated to $80^{\circ} \mathrm{C}, 90^{\circ} \mathrm{C}, 100^{\circ} \mathrm{C}$ can be amplified. Here, the Cycle threshold $(\mathrm{Ct})$ value of the beef meatball, pork meatball, and beef-pork meatball samples heated to $80{ }^{\circ} \mathrm{C}, 90{ }^{\circ} \mathrm{C}, 100{ }^{\circ} \mathrm{C}$ is significantly different from that of unheated beef and pork $(\mathrm{p}<0.05)$. However, there is no significant difference in the $\mathrm{Ct}$ value of the beef meatball, pork meatball, and beef-pork meatball samples heated to $80^{\circ} \mathrm{C}, 90^{\circ} \mathrm{C}, 100^{\circ} \mathrm{C}(\mathrm{p} \geq 0.05)$. It can be concluded that the beef and pork DNA in meatballs boiled at $80{ }^{\circ} \mathrm{C}$ to $100{ }^{\circ} \mathrm{C}$ is detectable by the RT-PCR.
\end{abstract}

Keywords: Beef, Heating, Pork, RT-PCR, Temperature

\section{Introduction}

Indonesia is a country with the largest Muslim population. For Muslims, the concept of halal and haram is a fundamental law in food consumption, in particular. Pork, for example, clearly haram (unlawful/forbidden) food. However, mixing pork with meat-based food is common in Indonesia to gain greater profit. This certainly raises concerns for Muslim community.

In 2019, the Gunung Kidul police officers arrested two suppliers for selling mixed beef and pork [1]. The same case happened in 2017 in Jember where a supplier of mixed beef and pork was taken into custody by the local police [2]. In the same year, the beef contamination with pork was found in branded beef sausages sold at Kranggan Market, Bringharjo Market and Pathuk Market in Yogyakarta[3]. To monitor halal products sold in the markets, an accurate analysis, especially regarding the pork and beef contents in various products is necessary. 
Some of the methods used to analyze the pork content in food samples are UV-Vis Spectroscopy [4], Spectrophotometry Fourier-Transform Infrared (FTIR) [5], Enzyme-Linked Immunosorbent Assay (ELISA) [6], Gold Nanoparticle [7], and Real Time Polymerase Chain Reaction (RT-PCR) [8]. Compared to other methods, the RT-PCR is often applied to analyze the pork content in food products due to its accuracy and specification in DNA detection [9]. It can even carry out sensitive DNA detection as low a concentrations as $1 \mathrm{pg} / \mathrm{ml}$ [10]. Such technique is suitable for heated products as small fragments of DNA can be identified and detected [11].

An interesting sample to determine for its halal content is meatballs. Meatballs are very popular among the majority of Indonesians. In the meatball making, the boiling process must be carried out to ripen the meat. Traditionally, meatballs are made by boiling the meat and spices at a temperature ranging from $80^{\circ} \mathrm{C}$ to $100^{\circ} \mathrm{C}$. In fact, heating the meat can cause DNA degradation. For this reason, this study attempts to analyze the effect of heating at $80^{\circ} \mathrm{C}$ to $100^{\circ} \mathrm{C}$ on beef and pork DNA detection in meatball products using the RT-PCR method.

\section{Method}

\subsection{Materials}

The materials include beef, pork, wheat flour, salt, garlic, pepper, PureLink ${ }^{\circledR}$ Genomic DNA Mini Kit, SensiFAST SYBR No-Rox (Bioline), isopropanolol absolute (Merk, Germany), $\mathrm{NaOH}$ (Merk, Germany), ethanol, aquabidest, and a pair of primer beef and pork.

Table 1. Primary base [12]

\begin{tabular}{ll}
\hline Primer & Base \\
\hline Beef Forward & 5' - CCCGATTCTTCGCTTTCCAT -3' \\
Beef Reverse & 5' - CTACGTCTGAGGAAATTCCTGTTG -3' \\
Pork Forward & 5' - CTTGCAAATCCTAACAGGCCTG -3' \\
Pork Reverse & 5' - CGTTTGCATGTAGATAGCGAATAAC -3' \\
\hline
\end{tabular}

\subsection{Instrument}

The instruments applied in this study include the Real Time PCR (q-Tower), multiwell plate 96 (Roche $\left.{ }^{\circledR}\right), 1.5$ volume microcentrifuge tube (Biogenix), micropipette (Biorad), centrifugator (5417R-Eppendrof), vortex (Horiba, Japan), digital waterbath (SB-100 Eyela), UV DNA spectrophotometer (DeNovix ${ }^{\circledR}$ ), and analytical scales (Horiba, Japan). 


\subsection{Procedure}

\section{Meatballs Making}

Beef, pork, the combination of beef and pork ( 9 grams each) were mixed with 1 gram of flour. Pepper and salt were then added. All ingredients were stirred until they were all mixed up and round like balls. The samples were boiled at $80^{\circ} \mathrm{C}, 90^{\circ} \mathrm{C}$, and $100^{\circ} \mathrm{C}$ for 1 hour.

\section{DNA Isolate}

Animal tissue preparation and cell lysis

$20 \mathrm{mg}$ of ground meatballs was put into a $1.5 \mathrm{ml}$ microcentrifugation tube and added with $600 \mu \mathrm{L}$ of nucleic lysis solution. The mixture was homogenized with a vortex for 15 seconds and incubated for 30 minutes at $65^{\circ} \mathrm{C}$.

\section{Cell lysis and Protein Precipitation.}

$3 \mu \mathrm{L}$ of RNAse solution was added to the incubated mixture. In turn, the mixture was incubated again at $37^{\circ} \mathrm{C}$ for 30 minutes. In the next step, $200 \mu \mathrm{L}$ of protein precipitation solution was added and vortexed. The mixture was let stand for 5 minutes at $5^{\circ} \mathrm{C}$ before it was centrifuged for 5 minutes at $16000 \mathrm{rpm}$ speed.

\section{DNA Precipitation and Rehydration.}

The precipitate and supernatant formed from the centrifugation were separated. $200 \mu \mathrm{L}$ of supernatant was taken and $600 \mu \mathrm{L}$ of isopropanol was then added. The resulting mixture was homogenized and centrifuged for 1 minute at $16,000 \mathrm{rpm}$ speed. The precipitate and the supernatant formed from the centrifugation were separated. The precipitate was added with $600 \mu \mathrm{L}$ of $70 \%$ ethanol, homogenized and centrifuged for 1 minute at 16,000 rpm speed. The ethanol-containing precipitate was evaporated using a hairdryer and in turn $50 \mu \mathrm{L}$ of DNA rehydration solution was added.

\section{DNA Isolate Analysis with UV Spectrophotometry}

The isolated DNA was analyzed using UV DNA Spectrophotometry. The DNA rehydration solution was used as a blank. About $1 \mu \mathrm{l}$ was placed on the sample port and was then analyzed. The sample port was cleaned and $1 \mu 1$ of the DNA sample was placed on the sample port again. The DNA sample was analyzed at $260 \mathrm{~nm}$ and $280 \mathrm{~nm}$ wavelengths.

\section{DNA amplification using Real-Time PCR}

The amplification was carried out with the composition of solutions shown in Table 2.

Table 2. RT-PCR Mix Composition

\begin{tabular}{cc}
\hline Reagent & Volume \\
\hline Sensi FAST SYBR No-ROX & $5 \mu \mathrm{l}$ \\
$10 \mu \mathrm{M}$ forward primer & $0.3 \mu \mathrm{l}$ \\
$10 \mu \mathrm{M}$ reverse primer & $0.3 \mu \mathrm{l}$ \\
Template & $1.4 \mu \mathrm{l}$ \\
Aquadest & $3 \mu \mathrm{l}$ \\
\hline
\end{tabular}




\section{Data Analysis}

The data obtained from the RT-PCR is the Ct value of the amplification process. A statistical analysis was carried out to examine the $\mathrm{Ct}$ value. The analysis here includes the parametric test if the normality and homogeneity of variance is met or the nonparametric test if the normality and homogeneity of variance is not met. In this study, the parametric test was conducted with One Way Analysis of Variance (ANOVA), while the nonparametric test was carried out using the Kruskall Wallis Test.

\section{Result}

The result of the purity test is illustrated in Table 3 . The highest concentration was found in control beef DNA $(164,648 \mathrm{ng} / \mu \mathrm{l})$ and the lowest concentration was seen in beef DNA heated to $100{ }^{\circ} \mathrm{C}(6.8 \mathrm{ng} / \mu \mathrm{l})$.

Table 3. The results of measurements of the concentration and purity of DNA isolates

\begin{tabular}{|c|c|c|c|}
\hline No. & Sample & Concentration $(\mathrm{ng} / \mu \mathrm{l})$ & $\begin{array}{c}\text { Purity }(\lambda 260 \mathrm{~nm} / \\
280 \mathrm{~nm})\end{array}$ \\
\hline 1. & Beef & 164.684 & 1.430 \\
\hline 2. & Pork & 15.050 & 1.320 \\
\hline 3. & Beef $80^{\circ} \mathrm{C}$ & 9.43 & 2.128 \\
\hline 4. & Beef $90^{\circ} \mathrm{C}$ & 8.0 & 1.593 \\
\hline 5. & Beef $100^{\circ} \mathrm{C}$ & 6.8 & 2.4 \\
\hline 6. & Pork $80^{\circ} \mathrm{C}$ & 54.33 & 1.734 \\
\hline 7. & Pork $90^{\circ} \mathrm{C}$ & 7.0 & 1.750 \\
\hline 8. & Pork $100^{\circ} \mathrm{C}$ & 17.45 & 1.700 \\
\hline 9. & Beef meatball $80^{\circ} \mathrm{C}$ & 14.00 & 1.781 \\
\hline 10. & Beef meatball $90^{\circ} \mathrm{C}$ & 25.81 & 1.896 \\
\hline 11. & Beef meatball $100^{\circ} \mathrm{C}$ & 17.70 & 1.654 \\
\hline 12. & Pork meatball $80^{\circ} \mathrm{C}$ & 34.75 & 1.760 \\
\hline 13. & Pork meatball $90^{\circ} \mathrm{C}$ & 46.40 & 1.758 \\
\hline 14. & Pork meatball $100^{\circ} \mathrm{C}$ & 13.65 & 1.784 \\
\hline 15. & Mixed meatball $80^{\circ} \mathrm{C}$ & 23.99 & 1.847 \\
\hline 16. & Mixed meatball $90^{\circ} \mathrm{C}$ & 30.94 & 1.827 \\
\hline 17. & Mixed meatball $100^{\circ} \mathrm{C}$ & 34.80 & 1.758 \\
\hline
\end{tabular}

The $\mathrm{Ct}$ value from amplification of beef, pork, beef meatballs, pork meatballs and mixed meatballs heated at $80^{\circ} \mathrm{C}, 90^{\circ} \mathrm{C}$ and $100^{\circ} \mathrm{C}$ can be seen in Table 4 .

Table 4. Value of $\mathrm{Ct}$ amplification process and Standard Deviation (SD)

\begin{tabular}{rlccc}
\hline No. & & Sampel & Ct & SD \pm \\
\hline 1. & Beef & 21.56 & 0.09 \\
2. & Pork & 18.08 & 0.01 \\
3. & Beef $80^{\circ} \mathrm{C}$ & 31.65 & 0.50 \\
4. & Beef $90^{\circ} \mathrm{C}$ & 31.59 & 0.40 \\
5. & Beef $100^{\circ} \mathrm{C}$ & 31.42 & 0.02 \\
\hline
\end{tabular}




\begin{tabular}{llll}
\hline 6. & Pork $80^{\circ} \mathrm{C}$ & 26.57 & 0.50 \\
7. & Pork $90^{\circ} \mathrm{C}$ & 21.35 & 0.14 \\
8. & Pork $100^{\circ} \mathrm{C}$ & 20.66 & 0.04 \\
9. & Beef meatball $80^{\circ} \mathrm{C}$ & 30.61 & 0.94 \\
10. Beef meatball $90^{\circ} \mathrm{C}$ & 31.37 & 0.14 \\
11. Beef meatball $100^{\circ} \mathrm{C}$ & 30.16 & 0.04 \\
12. Pork meatball $80^{\circ} \mathrm{C}$ & 24.97 & 1.78 \\
13. Pork meatball $90^{\circ} \mathrm{C}$ & 19.16 & 0.46 \\
14. Pork meatball $100^{\circ} \mathrm{C}$ & 22.30 & 0.10 \\
15. Mixed meatball with bovine primer $80^{\circ} \mathrm{C}$ & 33.23 & 1.20 \\
16. Mixed meatball with bovine primer $90^{\circ} \mathrm{C}$ & 31.56 & 0.31 \\
17. Mixed meatball with bovine primer $100^{\circ} \mathrm{C}$ & 32.15 & 0.21 \\
18. Mixed meatball with porcine primer $80^{\circ} \mathrm{C}$ & 21.77 & 0.11 \\
19. Mixed meatball with porcine primer $90^{\circ} \mathrm{C}$ & 22.96 & 0.67 \\
20. Mixed meatball with porcine primer $100^{\circ} \mathrm{C}$ & 25.95 & 2.83 \\
\hline
\end{tabular}

\section{Discussion}

\section{DNA Isolate}

The DNA isolate was carried out on beef and pork (as a control), beef meatballs, pork meatballs, and beef-pork meatballs using Wizard Genomic DNA extraction kit. The isolation process consists of cell and nucleus breakdown process, RNA degradation, protein precipitation, DNA precipitation and purification, and DNA rehydration. The cell and nucleus breakdown process is a process of destroying the integrity of the cell wall barrier. In this process, the nucleic lysis solution was used. In the DNA degradation step, RNAse as an enzyme that degrades RNA was given to remove it in solution [13]. The Next step was adding protein precipitation solution (PPS) to precipitate the protein so that the DNA strands were no longer coiled [14]. The DNA precipitation was carried out by adding isopropanol to the resulting supernatant. The DNA would appear as fine white threads [15]. Then, the precipitate was washed using $70 \%$ ethanol in order to make the DNA precipitate free from isopropanol and any remaining salt from the previous process [16]. The final stage was the resuspension of the DNA isolate by providing a DNA rehydration solution to the dried precipitate in order to turn the precipitate formed into a solution easier to examine.

\section{DNA Purity Test}

The DNA purity test was conducted to ensure the completion of the amplification process. The UV spectrophotometry at $260 \mathrm{~nm}$ and $280 \mathrm{~nm}$ wavelengths was used in performing the DNA isolate purity test. Nucleotides have a maximum absorption at $260 \mathrm{~nm}$ wavelength, whereas proteins have a maximum absorption at $280 \mathrm{~nm}$ wavelength [17]. A good purity value is obtained if the absorption ratio at 260 and 280 wavelengths is in $1.8-2.0$ range. DNA that has a purity above 1.0 is even acceptable and analyzed using the real-time PCR continues [18]. Based on the purity value, all samples could be continued in the PCR process. 


\section{Primary Specificity}

Beef and pork primers with forward and reverse sequencing primers were used in Tanabe's study in 2007 [12]. There was $50 \%$ of GC in in the forward bovine primer, and $45 \%$ of GC in the reverse primer respectively. In the meantime, there was $50 \%$ of GC in the forward porcine primer, and the reverse primer contained $40 \%$ of GC base. DNA that contains more GC bases will have more stable than the DNA with AT bases [19]. In 2017, Zilhadia conducted a specificity test on pork and beef primers using the NCBI BLAST [20]. However, in this study, the specificity test was carried out with agarose gel electrophoresis. The electrophoresis result showed the two pairs of primers used were specific for beef and pork DNA (the electrophoresis images are not shown).

\section{Determination of Optimal Amplification Method}

The temperature optimization was conducted for denaturation, annealing, and extension processes. The modification of annealing temperature affects the primer attachment process to the DNA template. If the annealing temperature is too high, the primer is unable to attach properly to the template. However, if the annealing temperature is too low, the primer will stick to an unspecified attachment site which will then amplify unexpected locus fragments [21]. The annealing temperature is determined by calculating the Tm, which is usually calculated based on $(\mathrm{Tm}-5)^{\circ} \mathrm{C}$ to $(\mathrm{Tm}+5)^{\circ} \mathrm{C}[22]$. The $\mathrm{Tm}$ generated from the primary protocol for forward and reverse beef primers was $55.4^{\circ} \mathrm{C}$, forward pork primers about $56.4^{\circ} \mathrm{C}$ and reverse primers about $54.3^{\circ} \mathrm{C}$ respectively. At the annealing stage, the temperature used is equal to $60^{\circ} \mathrm{C}$. In the meantime, the denaturation and extension temperatures refer to the SensiFAST SYBR No-ROX Kit protocol, $95^{\circ} \mathrm{C}$ and $72^{\circ} \mathrm{C}$ respectively. The determination of the optimal concentration of DNA isolate is needed for some considerations. If it is too high, it can increase the chance of mispriming. However, if it is too low, the primer may not reach the target. [23]. The concentration range in this study was made equal, at a concentration value of $5-10 \mathrm{ng} / \mu \mathrm{l}$.

\section{The DNA Amplification of Control Beef and Pork, Beef Meatballs, Pork Meatballs and Beef-} Pork Meatballs Heated to $80^{\circ} \mathrm{C}, 90^{\circ} \mathrm{C}$ and $100^{\circ} \mathrm{C}$

The Ct value of the control beef DNA amplification process using beef primer is 21.76, whereas the $\mathrm{Ct}$ value of pork DNA amplification process using pork primer is 18.08. The $\mathrm{Ct}$ value has indicated the control beef and pork DNA amplification process went well. As indicated by the $\mathrm{Ct}$ value, the pork DNA amplification was slightly lower than the beef DNA amplification.

The RT-PCR test was carried out on 3 samples of beef and pork heated to $80^{\circ} \mathrm{C}, 90^{\circ} \mathrm{C}$, and $100^{\circ} \mathrm{C}$ respectively. The $\mathrm{Ct}$ value in beef samples with beef primer at $80^{\circ} \mathrm{C}, 90^{\circ} \mathrm{C}, 100^{\circ} \mathrm{C}$ was 31.65 $\pm 0.50,31.59 \pm 0.40$ and $31.42 \pm 0.02$, respectively. The $\mathrm{Ct}$ value in pork samples with pork primer at $80{ }^{\circ} \mathrm{C}, 90{ }^{\circ} \mathrm{C}, 100{ }^{\circ} \mathrm{C}$ was $26.57 \pm 0.5 .38,21.35 \pm 0.14$ and $20.66 \pm 0.004$, respectively. The $\mathrm{Ct}$ value of heated beef and pork was higher than that of unheated beef and pork. This shows the heating process has given an influence on the beef and pork DNA amplification process. According to the theory, heating will cause DNA degradation, but the DNA can still be amplified using polymerase enzymes. However, there was no significant difference in the $\mathrm{Ct}$ value of beef and pork heated to $80^{\circ} \mathrm{C}, 90^{\circ} \mathrm{C}$ and $100^{\circ} \mathrm{C}$. This means temperature differences ranging from $80^{\circ} \mathrm{C}$ to $100^{\circ} \mathrm{C}$ did give any significant effect.

The next amplification was performed on 3 samples of beef meatballs and pork meatballs heated to $80^{\circ} \mathrm{C}, 90^{\circ} \mathrm{C}$, and $100^{\circ} \mathrm{C}$. The $\mathrm{Ct}$ value of the beef meatball samples with beef primers at 
$80^{\circ} \mathrm{C}, 90^{\circ} \mathrm{C}, 100^{\circ} \mathrm{C}$ was $30.61 \pm 0.94,31.37 \pm 0.14$, and $30.16 \pm 0.04$ respectively. Meanwhile, the $\mathrm{Ct}$ value of pork meatball samples with pork primer was $80^{\circ} \mathrm{C}, 90^{\circ} \mathrm{C}, 100^{\circ} \mathrm{C}$ was $24.97 \pm 7.78,19.16$ $\pm 0.46,22.30 \pm 0.10$, respectively. The $\mathrm{Ct}$ value in the amplification results of beef and pork meatballs at $80{ }^{\circ} \mathrm{C}-100{ }^{\circ} \mathrm{C}$ range which was statistically tested indicated no significant difference. The same case happened to the mixed beef and pork meatballs. The $\mathrm{Ct}$ value of the mixed meatball samples with bovine primer at $80^{\circ} \mathrm{C}, 90^{\circ} \mathrm{C}, 100^{\circ} \mathrm{C}$ was $33.23 \pm 1.20,31.56 \pm 0.31$, and $32.15 \pm 0.21$ respectively, whereas the $\mathrm{Ct}$ value with porcine primer was equal to $21.77 \pm 0.11,22.96 \pm 0.67$, and $25.95 \pm 4.83$, respectively.

Sakalar et al, 2012 conducted some test on beef, pork, and chicken by heating the samples in an oven to $30^{\circ} \mathrm{C}, 60^{\circ} \mathrm{C}, 90^{\circ} \mathrm{C}, 120^{\circ} \mathrm{C}, 150^{\circ} \mathrm{C}, 180^{\circ} \mathrm{C}$, and $210^{\circ} \mathrm{C}$. The test discovered the temperature and heating duration affected the results of Real Time PCR detection; the higher the heating temperature and time, the higher the amplification value of the sample [24]. However, this study has shown different results probably due to the close temperature ranges. In the study conducted by Karni et al in 2013, a DNA degradation test was made using the agarose electrophoresis method in which the pUC19 DNA isolates were heated. The heating was made at $95^{\circ} \mathrm{C}, 130^{\circ} \mathrm{C}, 140^{\circ} \mathrm{C}, 150^{\circ} \mathrm{C}$, $160^{\circ} \mathrm{C}, 170^{\circ} \mathrm{C}, 180^{\circ} \mathrm{C}$, and $190^{\circ} \mathrm{C}$ respectively. As the result, DNA began to degrade at $130^{\circ} \mathrm{C}$ and reached complete degradation at $190^{\circ} \mathrm{C}$ [25]. Boiling in the process of making meatballs at $80^{\circ} \mathrm{C}$ to $100^{\circ} \mathrm{C}$ did not affect the $\mathrm{Ct}$ value in the amplification process. In this regard, the analysis of differences in beef and pork can still be conducted with good degree of accuracy.

\section{Conclusions}

Referring to the results and discussion, boiling beef, pork, beef meatballs, pork meatballs and beef-pork meatballs at $80^{\circ} \mathrm{C}, 90^{\circ} \mathrm{C}$, and $100^{\circ} \mathrm{C}$ is significantly different from the unheated beef and pork $(\mathrm{p} \leq 0.05)$. However, the heating process in beef, pork, beef meatball, pork meatball, and beefpork meatball samples at different temperature $\left(80^{\circ} \mathrm{C}, 90^{\circ} \mathrm{C}\right.$, and $\left.100^{\circ} \mathrm{C}\right)$ did not show any significant difference $(\mathrm{p} \geq 0.05)$. This means the DNA heated at $100^{\circ} \mathrm{C}$ could be amplified. For this reason, mixing pork and beef in the process of making meatballs heated to $100^{\circ} \mathrm{C}$ was detectable and analyzable.

\section{References}

[1] M. Yuwon. : Jual daging sapi dioplos babi, 2 pedagang diamankan. (2019). https://yogyakarta.kompas.com/read/2019/01/23/15022201/jual-daging-sapi-dioplos-babi-2pedagang-diamankan?page $=$ all.

[2] A. Faizal. : Polisi jember tangkap penjual daging sapi yang dicampur daging babi. (2017). https://regional.kompas.com/read/2017/02/22/06265601/polisi.jember.tangkap.penjual.daging.sapi.ya ng.dicampur.daging.babi.

[3] V. A. Priyanka, S. Ristiarini, and P. Yuda. : Deteksi cemaran daging babi pada produk sosis sapi di kota yogyakarta dengan metode Polymerase Chain Reaction. (2017). http://e-journal.uajy.ac.id/12587/

[4] D. Ardilla, M. Taufik, D.M. Tarigan, M. Thamrin, M. Razali, and H.S. Siregar.: Analisis lemak babi pada produk pangan olahan menggunakan spektroskopi UV-Vis. Jurnal Teknologi Pangan dan Hasil Pertanian. vol. 1, no. 2 (2018). Doi: 10.30596/agrin.v1i2.2011. 
[5] B. A. Permana. : Penelusuran deteksi lemak babi dalam campuran lemak dengan FTIR. Institut Pertanian Bogor. (2014). https://repository.ipb.ac.id/handle/123456789/72803

[6] I. E. Rohima, I.S.Nurminabari. : Identifikasi protein hewani pada produk bumbu instan dengan metode elisa (Enzyme Linked Immunosorbent Assay). Pasundan Food Technology Journal, vol. 5, no. 3, pp. 167-169 (2018).

[7] M. E. Ali, U. Hashim, S. Mustafa, Y. B. CheMan, and K. N. Islam.: Gold nanoparticle sensor for the visual detection of pork adulteration in meatball formulation. Journal of Nanomaterials. vol. 2012 (2011). Doi: 10.1155/2012/103607.

[8] L. Wulandari.: Uji deteksi cemaran daging babi pada bakso sapi di kecamatan ciputat menggunakan real time polymerase chain reaction (RT-PCR). UIN Syarif Hidayatullah Jakarta (2018). https://repository.uinjkt.ac.id/dspace/bitstream/123456789/47579/1/LAELA\%20WULANDARIFIKES.pdf

[9] A. Farouk, M. F. Batcha, R. Greiner, H. M. Salleh, M. R. Salleh, and A. R. Sirajudin.: The use of a molecular technique for the detection of porcine ingredients in the Malaysian food market. Saudi Medical Journal. vol. 27, no. 9, pp. 1397-1400 (2006).

[10] H. Cai, X. Gu, M. S. Scanlan, D. H. Ramatlapeng, and C. R. Lively.: Real-time PCR assays for detection and quantitation of porcine and bovine DNA in gelatin mixtures and gelatin capsules. Journal Food Composition Analysis. vol. 25, no. 1, pp. 83-87 (2012). Doi: 10.1016/j.jfca.2011.06.008.

[11] H. Hird, J Chisholm, A Sanches, M. Hernandez, R. Goodier, K Schneede, C Boltz and B Popping. : Effect of heat and pressure processing on DNA fragmentation and implications for the detection of meat using a real-time polymerase chain reaction. Food Additives Contamination. vol. 23, no. 7, pp. 645-650 (2006). Doi: 10.1080/02652030600603041.

[12] S. Tanabe, M. Hase, T. Yano, M. Sato, T. Fujimura, and H. Akiyama. : A Real-Time Quantitative PCR detection method for pork, chicken, beef, mutton, and horseflesh in foods. Bioscience Biotechnology and Biochemical, vol. 71, no. 12, pp. 3131-3135 (2007). Doi: 10.1271/bbb.70683.

[13] K. Wilson and J. M. Walker.: Principles and techniques of biochemistry and molecular biology, 7 th ed. Cambridge University Press. (2009).

[14] M. Faatih.: Isolasi dan digesti DNA kromosom. Sains dan Teknologi. vol. 10, no. 1, pp. 61-67 (2009). https://publikasiilmiah.ums.ac.id/handle/11617/432.

[15] E. Yulianti. : Pengembangan teknik isolasi DNA tumbuhan menggunakan detergen komersial. Universitas Negeri Yogyakarta. Yogyakarta (2006). https://eprints.uny.ac.id/11869/

[16] [Kamaliah.: Perbandingan metode ekstraksi DNA phenol-chloroform dan kit extraction pada sapi Aceh dan sapi Madura.Jurnal Ilmiah Biologi, Teknologi dan Kependidikan. vol. 5, no. 1, pp. 60-65 (2017).

[17] A. Tenriulo, E. Suryati, A. Parenrengi, and Rosmiat. : Ekstraksi DNA rumput laut Kappaphycus alvarezii dengan metode fenol kloroform. Buletin Teknik Litkayasa Akuakultur. vol. 2, no. 2, p. 5 (2001).

[18] [A. Kusumadewi, S. E. Kusuma, and A. Yudianto. : Analisis DNA Jaringan lunak manusia yang terpapar formalin dalam interval waktu 1 bulan selama 6 bulan pada lokus D13S317 dengan metode STR-PCR. Jurnal Bioscience. vol. 14, no. 2, p. 7.(2012)

[19] O. F. Borisova, A. K. Shchyolkina, B. K. Chernov, and N. A. Tchurikov.: Relative stability of AT and GC pairs in parallel DNA duplex formed by a natural sequence. FEBS Lett., vol. 322, no. 3, pp. 304 306, (1993). Doi: 10.1016/0014-5793(93)81591-M.

[20] [Z. Zilhadia, A. N. Izzah, and O. S. Betha.: Perbandingan metode SYBR Green dan Hydrolysis Probe dalam analisis DNA gelatin sapi dan gelatin babi menggunakan Real Time Polymerase Chain Reaction. Jurnal Sains Farmasi dan Klinis. vol. 4, no. 1, p. 16. (2017). Doi: 10.29208/jsfk.2017.4.1.194.

[21] M. R. Green and J. Sambrook.: Molecular cloning: a laboratory manual. 4th ed. Cold Spring Harbor, N.Y: Cold Spring Harbor Laboratory Press (2012).

[22] D. Handoyo and A. Rudiretna. : Prinsip umum dan pelaksanaan Polymerase Chain Reaction (PCR). Unitas. vol.9, no.1,. (2001). 
[23] E. Sulistyaningsih.: Polymerase Chain Reaction (PCR): Era Baru Diagnosis Dan Manajemen Penyakit Infeksi. Lab Fisiolologi Fakultas Kedokteran. Jember, vol. 1, no. 1, pp. 16-25 (2007).

[24] E. Şakalar, M. F. Abasiyanik, E. Bektik, and A. Tayyrov.: Effect of heat processing on DNA quantification of meat species. J. Food Sci., vol. 77, no. 9, pp. 40-44, (2012). Doi: 10.1111/j.17503841.2012.02853.x.

[25] M. Karni, D. Zidon, P. Polak, Z. Zalevsky, and O. Shefi.: Thermal degradation of DNA. DNA celluler biology. vol. 32, no. 6, pp. 1-4 (2013). Doi: 10.1089/dna.2013.2056. 